ARTICLE

\title{
Solid solution for catalytic ammonia synthesis from nitrogen and hydrogen gases at $50^{\circ} \mathrm{C}$
}

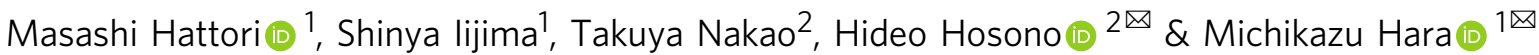

The lack of efficient catalysts for ammonia synthesis from $\mathrm{N}_{2}$ and $\mathrm{H}_{2}$ gases at the lower temperature of ca. $50^{\circ} \mathrm{C}$ has been a problem not only for the Haber-Bosch process, but also for ammonia production toward zero $\mathrm{CO}_{2}$ emissions. Here, we report a new approach for low temperature ammonia synthesis that uses a stable electron-donating heterogeneous catalyst, cubic $\mathrm{CaFH}$, a solid solution of $\mathrm{CaF}_{2}$ and $\mathrm{CaH}_{2}$ formed at low temperatures. The catalyst produced ammonia from $\mathrm{N}_{2}$ and $\mathrm{H}_{2}$ gases at $50^{\circ} \mathrm{C}$ with an extremely small activation energy of $20 \mathrm{~kJ} \mathrm{~mol}^{-1}$, which is less than half that for conventional catalysts reported. The catalytic performance can be attributed to the weak ionic bonds between $\mathrm{Ca}^{2+}$ and $\mathrm{H}^{-}$ions in the solid solution and the facile release of hydrogen atoms from $\mathrm{H}^{-}$sites.

\footnotetext{
${ }^{1}$ Laboratory for Materials and Structures, Tokyo Institute of Technology, 4259 Nagatsuta, Midori-ku, Yokohama 226-8503, Japan. ${ }^{2}$ Materials Research Center for Element Strategy, Tokyo Institute of Technology, 4259 Nagatsuta, Midori-ku, Yokohama, Kanagawa 226-8503, Japan.

凶email: hosono@msl.titech.ac.jp; mhara@msl.titech.ac.jp
} 
T he Haber-Bosch process currently enables the provision of food for over $70 \%$ of the world's population, consuming $2 \%$ of global energy and generating 3\% of global $\mathrm{CO}_{2}$ emissions ${ }^{1,2}$. These values would steeply increase by a rapid increase of the human population. Highly efficient conversion of $\mathrm{N}_{2}$ and $\mathrm{H}_{2}$ to ammonia with low-energy consumption has remained a challenge since the creation of the Haber-Bosch process, where sustainable ammonia production using natural energy is the ultimate goal. Ammonia is equilibrated in $\mathrm{N}_{2}$ and $\mathrm{H}_{2}$. Figure 1a demonstrates the correlation of the theoretical ammonia yield with reaction pressure and temperature. As the reaction temperature increases, ammonia decomposition as an endothermic reaction exceeds ammonia formation, an exothermic reaction, which decreases the ammonia yield. For this reason, the reaction system must therefore be further pressurized with an increase in the reaction temperature to obtain the same ammonia yield; high reaction temperature causes high pressurization, which requires large energy consumption for both heating and pressurization. The iron-based catalysts used in the present Haber-Bosch process are effective for ammonia synthesis above $350{ }^{\circ} \mathrm{C}$, so that the maximum ammonia yield is at most $30-40 \%$, despite excess pressurization ( $>10-20 \mathrm{MPa}$ ) accompanied by large energy consumption. This is a serious drawback in sustainable ammonia production without the use of fossil fuels. While wind power generation has been reported to be compatible with the Haber-Bosch process, the process itself consumes $40-50 \%$ of the electric power generated by wind turbine, and thereby electric power available for $\mathrm{H}_{2}$ production is considerably limited ${ }^{3}$. Figure $1 \mathrm{a}$ also indicates that the ammonia yield exceeds $98 \%$ at ca. $50{ }^{\circ} \mathrm{C}$ regardless of pressures, and there is no significant difference in ammonia yield among pressures below this temperature. Thus, a lower temperature is favorable for ammonia production with respect to yield and energy consumption, and more efficient ammonia production is required to overcome the kinetic barrier at lower temperature to achieve the equilibrium. However, conventional catalysts equally lose the catalytic activity for ammonia formation from $\mathrm{N}_{2}$ and $\mathrm{H}_{2}$ at $100-200^{\circ} \mathrm{C}$, even if they exhibit high catalytic performance at high temperatures, as shown in Fig. 1a. Lowering the temperature for a loss of activity below $50{ }^{\circ} \mathrm{C}$ would largely enhance the catalytic activity for ammonia synthesis at low-temperature range below $300^{\circ} \mathrm{C}$. While there has been significant progress in homogeneous catalytic systems to synthesize ammonia from $\mathrm{N}_{2}$ and $\mathrm{H}^{+}$activated by specific and nonreusable reagents below room temperature ${ }^{4,5}$, guiding principles to lower the temperature for a loss of activity on ammonia synthesis from $\mathrm{N}_{2}$ and $\mathrm{H}_{2}$ have yet to be clarified.

Thus, the lack of catalysts that are workable at lower temperatures has remained a problem for the Haber-Bosch process for over a century, and has also prevented sustainable ammonia production toward zero $\mathrm{CO}_{2}$ emissions. We have begun to reexamine the low-temperature kinetics of ammonia synthesis catalysts to find a route for low-temperature ammonia production. Figure $1 \mathrm{~b}$ shows Arrhenius plots for a commercial Fe catalyst $^{6}$ with ammonia formation rates that were both measured $\left(\mathrm{r}^{\mathrm{M}} \mathrm{NH}_{3}\right)$ and estimated from the Arrhenius equation $\left(\mathrm{r}^{\mathrm{E}} \mathrm{NH}_{3}\right)$. The reaction rate follows the Arrhenius equation as long as the reaction mechanism is unchanged in the temperature range; therefore, the reaction rate at a specific temperature was estimated using the Arrhenius equation. The difference between $\mathrm{r}^{\mathrm{M}} \mathrm{NH}_{3}$ and $\mathrm{r}^{\mathrm{E}} \mathrm{NH}_{3}$ increases with a decrease in the temperature below $300^{\circ} \mathrm{C}$. The Arrhenius equation predicted a sufficient amount of ammonia to form at $100^{\circ} \mathrm{C}$. However, no ammonia formation was detected below $150^{\circ} \mathrm{C}$, which brought the natural logarithm of the rate close to $-\infty$. Even if the catalyst amount and space velocity were increased significantly, ammonia formation was not observed below $150^{\circ} \mathrm{C}$. Taking into account the detection sensitivity of the ammonia analysis methods, the rate of ammonia formation was expected to be less than nano $\mathrm{mol} \mathrm{h}^{-1} \mathrm{~g}^{-1}$. This means that the catalyst cannot act for ammonia synthesis at all below the temperature. The same phenomenon was confirmed in several representative catalytic systems for the synthesis of ammonia from $\mathrm{N}_{2}$ and $\mathrm{H}_{2}$ (Supplementary Table 1). This cannot be simply attributed to deactivation by ammonia adsorbed on the catalyst, because ammonia that adsorbs on transition metals (TMs) such as Fe and Ru will desorb below room temperature ${ }^{7}$. Ammonia formation from $\mathrm{N}_{2}$ and $\mathrm{H}_{2}$ over catalysts proceeds through the dissociative adsorption of $\mathrm{N}_{2}\left(\mathrm{~N}_{2} \rightarrow 2 \mathrm{~N}\right)$, followed by the hydrogenation of nitrogen adatoms $\left(\mathrm{N} \rightarrow \mathrm{NH}_{3}\right)$. The former step has a higher energy barrier than the latter that proceeds on TM surfaces at room temperature to $100^{\circ} \mathrm{C}^{8}$. It is wellknown that the cleavage of $\mathrm{N}_{2}$ molecules with ammonia synthesis catalysts is largely enhanced by electron donation from electrondonating materials into the $\pi^{*}$ orbitals of $\mathrm{N} \equiv \mathrm{N}$ via the d-orbitals of $\mathrm{TMs}^{9-11}$, and the electron-donating capability of the TM itself is almost independent of the temperature below $200^{\circ} \mathrm{C}^{12,13}$ (see Supplementary Discussion). A decrease in the electron-donating capability has been purported as one possible explanation for the lack of ammonia synthesis by catalysis at low temperatures.
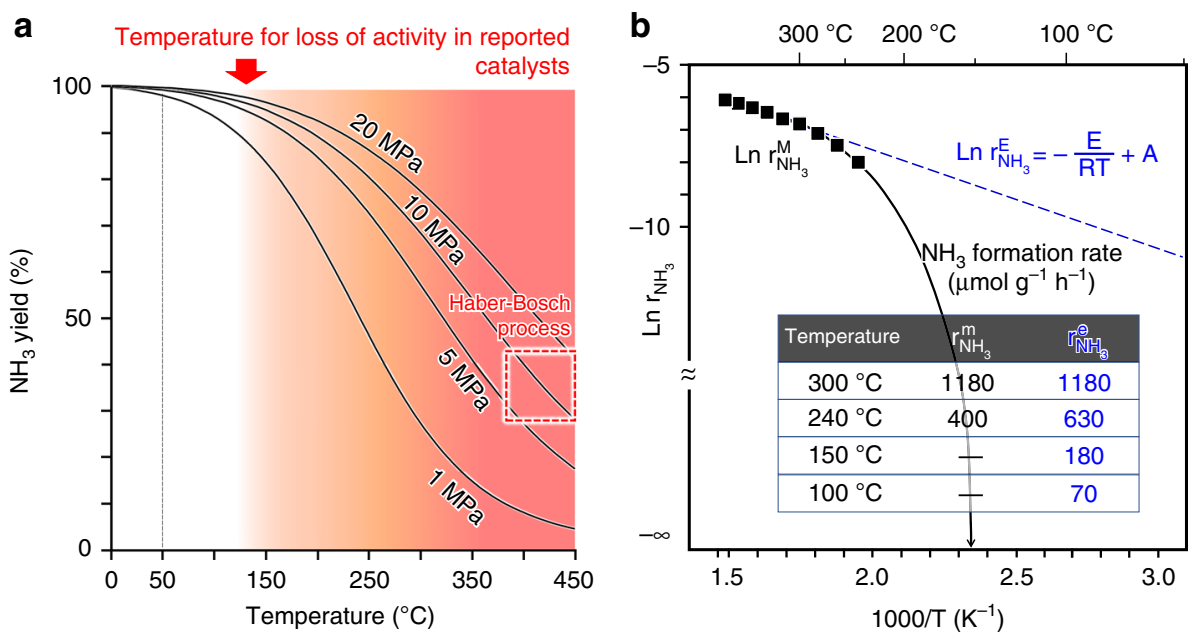

Fig. 1 Ammonia synthesis from $\mathbf{N}_{\mathbf{2}}$ and $\mathbf{H}_{\mathbf{2}}$. a Correlation of ammonia yield with temperature and pressure. $\mathbf{b}$ Arrhenius plots for ammonia synthesis over a commercial Fe catalyst. 

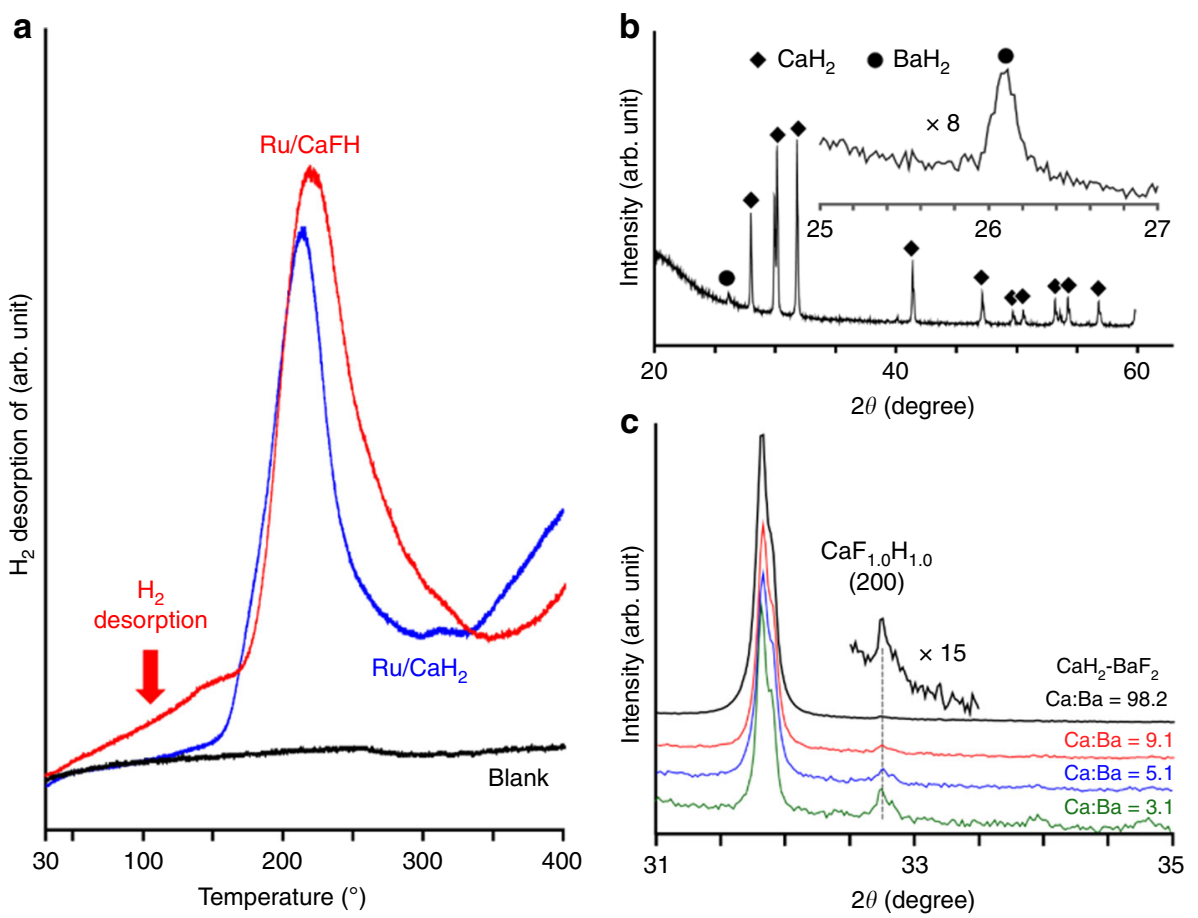

Fig. $2 \mathrm{H}_{2}$-TPD and XRD for prepared materials. a $\mathrm{H}_{2}$-TPD profiles for $\mathrm{Ru} / \mathrm{CaH}_{2}$ and $\mathrm{Ru} / \mathrm{CaFH}$ after ammonia synthesis reaction at $3400^{\circ} \mathrm{C}$, followed by cooling down below $20^{\circ} \mathrm{C}$. TPD measurements were performed under $\mathrm{Ar}$ flow $\left(1^{\circ} \mathrm{C} \mathrm{min}{ }^{-1}\right)$. $\mathbf{b}$ XRD pattern for $\mathrm{CaH}_{2}-\mathrm{BaF} 2 \mathrm{mixture}(\mathrm{Ca}: \mathrm{Ba}=98: 2)$ after heating at $340^{\circ} \mathrm{C}$ for $10 \mathrm{~h}$ in $\mathrm{H}_{2}$. c Narrow-range XRD patterns for $\mathrm{CaH}_{2}-\mathrm{BaF}_{2}$ mixtures ( $\mathrm{Ca}: \mathrm{Ba}=98: 2,9: 1,5: 1$, and 3:1) after heating at $340{ }^{\circ} \mathrm{C}$ for $10 \mathrm{~h}$ in $\mathrm{H}_{2}$.

Therefore, stable materials that exhibit high electron-donating capability at low temperatures may lead to the realization of lowtemperature ammonia synthesis.

Here we present a new approach for low-temperature ammonia synthesis that uses a stable electron-donating heterogeneous catalyst, $\mathrm{Ru}$ nanoparticle-deposited cubic $\mathrm{CaFH}$ solid solution. The catalyst produces ammonia from $\mathrm{N}_{2}$ and $\mathrm{H}_{2}$ gases at $50{ }^{\circ} \mathrm{C}$ with an extremely small activation energy of $20 \mathrm{~kJ} \mathrm{~mol}^{-1}$, which is less than half that for conventional catalysts reported. The catalytic performance can be attributed to the weak ionic bonds between $\mathrm{Ca}^{2+}$ and $\mathrm{H}^{-}$ions in the solid solution and the facile release of hydrogen atoms from $\mathrm{H}^{-}$sites.

\section{Results}

CaFH solid solution as a strong electron-donating material. As a first step to verify the working hypothesis and to prepare such electron-donating materials, we have focused on calcium hydride $\left(\mathrm{CaH}_{2}\right)$, a familiar dehydrating agent, because of its simplicity. TM nanoparticles deposited on $\mathrm{CaH}_{2}$ abstract $\mathrm{H}$ atoms from the nearsurface $\mathrm{CaH}_{2}$ due to substantial interaction between the TM and $\mathrm{H}^{-}$, and the $\mathrm{H}$ atoms move on to the metal nanoparticles and desorb as $\mathrm{H}_{2}$ molecules, leaving electrons in the $\mathrm{H}^{-}$vacancy of $\mathrm{CaH}_{2}$ $\left(\mathrm{CaH}_{2} \rightarrow \mathrm{Ca}^{2+} \mathrm{H}^{-}{ }_{(2-x)} \mathrm{e}^{-}{ }_{x}+x \mathrm{H}\right)^{14}$. The resulting $\mathrm{Ca}^{2+} \mathrm{H}^{-}{ }_{(2-x)} \mathrm{e}^{-}{ }_{x}$ behaves as a stable surface electride with a small work function $(\Phi=2.7 \mathrm{eV})$ comparable with that of metallic $\mathrm{Li}^{15}$. The strong electron donation from $\mathrm{Ca}^{2+} \mathrm{H}^{-}{ }_{(2-x)} \mathrm{e}^{-}{ }_{x}$ to the TM nanoparticles enhances the cleavage of $\mathrm{N}_{2}$ molecules, which leads to high catalytic performance for ammonia synthesis ${ }^{14}$. Supplementary Table 1 shows that the difference between the $\mathrm{r}^{\mathrm{M}} \mathrm{NH}_{3}$ and $\mathrm{r}^{\mathrm{E}} \mathrm{NH}_{3}$ rates for the formation of ammonia over Ru-deposited $\mathrm{CaH}_{2}\left(\mathrm{Ru} / \mathrm{CaH}_{2}\right)$ was not negligible at $\leq 200^{\circ} \mathrm{C}$, as with other catalysts; however, the catalyst was not at all active for ammonia formation at $150^{\circ} \mathrm{C}$. The temperature that eliminates the activity of $\mathrm{Ru} / \mathrm{CaH}_{2}$ is therefore between 150 and $200^{\circ} \mathrm{C}$, which is similar to that for conventional catalysts (Supplementary Table 1). A $\mathrm{H}_{2}$-temperature-programmed desorption (TPD) profile for $\mathrm{Ru} / \mathrm{CaH}_{2}$ (Fig. 2a) revealed that the $\mathrm{H}_{2}$ desorption-onset temperature was almost identical to the temperature where the catalytic activity of $\mathrm{Ru} / \mathrm{CaH}_{2}$ is lost. Formation of a strong electron-donating material is a determinant for ammonia formation over $\mathrm{Ru} / \mathrm{CaH}_{2}$ at low temperatures. Therefore, lowering of the onset temperature for $\mathrm{H}_{2}$ desorption would lead to a catalytic system for ammonia synthesis at lower temperatures.

Here, we have adopted a new strategy based on classical theory to lower the electride formation temperature: the introduction of $\mathrm{F}^{-}$anions into $\mathrm{CaH}_{2} . \mathrm{F}^{-}$is an extremely hard base in hard and soft acids and bases (HSAB), and the $\mathrm{Ca}-\mathrm{F}$ ionic bond $(529 \mathrm{~kJ}$ $\left.\mathrm{mol}^{-1}\right)$ is harder than the $\mathrm{Ca}-\mathrm{H}$ bond $\left(224 \mathrm{~kJ} \mathrm{~mol}^{-1}\right)^{16}$. Replacing a part of $\mathrm{H}^{-}$in $\mathrm{CaH}_{2}$ with $\mathrm{F}^{-}$would weaken ionic bonds between $\mathrm{Ca}^{2+}$ and $\mathrm{H}^{-}$, thereby lowering the temperature for the release of $\mathrm{H}$ atoms from the material. This replacement would increase the energy of electrons trapped at $\mathrm{H}^{-}$vacancies due to electron repulsion between the electron and $\mathrm{F}^{-}$, which would cause a reduction in the work function of the surface region and in turn enhance the electron-donating power. In this study, $\mathrm{F}^{-}$was introduced into $\mathrm{CaH}_{2}$ by heating a simple mixture of $\mathrm{CaH}_{2}$ and $\mathrm{BaF}_{2}$ powders in a flow of $\mathrm{H}_{2}$ at $340^{\circ} \mathrm{C}$. A widerange X-ray diffraction (XRD) pattern (Fig. 2b) of the resultant sample $(\mathrm{Ca} / \mathrm{Ba}$ atomic ratio $=98: 2)$ indicated that the sample is mainly composed of $\mathrm{CaH}_{2}$. Diffraction peaks of $\mathrm{BaF}_{2}$ or $\mathrm{CaF}_{2}$ were not observed in the XRD pattern, whereas the diffraction peaks due to $\mathrm{BaH}_{2}$ were apparent (Supplementary Fig. 1). Consequently, $\mathrm{CaF}_{2}$ is not formed in the heated mixture, despite the complete replacement of $\mathrm{F}^{-}$in $\mathrm{BaF}_{2}$ with $\mathrm{H}^{-}$derived from $\mathrm{CaH}_{2} . \mathrm{CaH}_{2}-\mathrm{BaF}_{2}$ mixtures in various $\mathrm{CaH}_{2} / \mathrm{BaF}_{2}$ ratios were heated in $\mathrm{H}_{2}$ to identify the material formed in the heated $\mathrm{CaH}_{2}-\mathrm{BaF}_{2}$ mixture. Figure $2 \mathrm{c}$ shows narrow-range XRD patterns $\left(2 \theta=31-35^{\circ}\right)$ of heated $\mathrm{CaH}_{2}-\mathrm{BaF}_{2}$ mixtures $(\mathrm{Ca} / \mathrm{Ba}$ atomic ratios of 98:2, 9:1, 5:1, and 3:1), where an asymmetrical diffraction assignable to (200) of the cubic $\mathrm{CaF}_{1.0} \mathrm{H}_{1.0}$ solid solution appears 
at $2 \theta=32.7^{\circ 17}$. It is well-known that orthorhombic $\mathrm{CaH}_{2}$ is transformed into a cubic structure in the formation of cubic $\mathrm{CaFH}$ solid solution ${ }^{17}$. The diffraction peak intensity increased, but was not shifted with an increase in the Ba content. In order to clarify the characteristics of $\mathrm{CaF}_{1.0} \mathrm{H}_{1.0}$ solid solution formed on $\mathrm{CaH}_{2}-\mathrm{BaF}_{2}$ mixtures, $\mathrm{CaF}_{x} \mathrm{H}_{2-x}$ solid solution (denoted as $\mathrm{CaF}_{x} \mathrm{H}_{2-x}-\mathrm{CaF}_{2}$ ) was prepared by heating mixtures of orthorhombic $\mathrm{CaH}_{2}$ and cubic $\mathrm{CaF}_{2}$ at $550{ }^{\circ} \mathrm{C}$, a conventional method ${ }^{17}$. $\mathrm{XRD}$ patterns of $\mathrm{CaF}_{x} \mathrm{H}_{2-x}-\mathrm{CaF}_{2}(1.0 \leq x \leq 1.6)$ (Supplementary Fig. 2) elucidated that the (200) diffraction for the cubic $\mathrm{CaF}_{x} \mathrm{H}_{2-}$ ${ }_{x}-\mathrm{CaF}_{2}$ is sensitive to the $\mathrm{F}^{-}$concentration and shifts from $2 \theta=$ $32.7^{\circ}$ to lower angles with decreasing $\mathrm{F}^{-}$concentration ${ }^{17}$. These results suggest that heating a $\mathrm{CaH}_{2}-\mathrm{BaF}_{2}$ mixture at $340{ }^{\circ} \mathrm{C}$ forms the most stable $\mathrm{CaF}_{1.0} \mathrm{H}_{1.0}$ on $\mathrm{CaH}_{2}$. In $\mathrm{X}$-ray photoelectron spectroscopy (XPS) measurements for heated $\mathrm{CaH}_{2}-\mathrm{BaF}_{2}$ mixtures $(\mathrm{Ca} / \mathrm{Ba}$ atomic ratio of $98: 2), \mathrm{CaF}_{\mathrm{x}} \mathrm{H}_{2-x}-\mathrm{CaF}_{2}(x=1)$ and $\mathrm{CaH}_{2}$ (Supplementary Fig. 3), the Ca $2 \mathrm{p}$ peaks for both heated $\mathrm{CaH}_{2}-\mathrm{BaF}_{2}$ mixtures and $\mathrm{CaF}_{x} \mathrm{H}_{2-x}-\mathrm{CaF}_{2}(x=1)$ appeared at $346.5 \mathrm{eV}$, which is lower than that for $\mathrm{CaH}_{2}(347.3 \mathrm{eV})$ and supports the formation of the $\mathrm{CaF}_{1.0} \mathrm{H}_{1.0}$ solid solution on the surface of a small amount of $\mathrm{BaF}_{2}$-added $\mathrm{CaH}_{2}$. Next, $\mathrm{Ru}$ nanoparticles $\left(12 \mathrm{wt} \%\right.$ ) were deposited on $\mathrm{CaF}_{1.0} \mathrm{H}_{1.0}$ phase obtained by heating a $\mathrm{CaH}_{2}-\mathrm{BaF}_{2}(\mathrm{Ca}: \mathrm{Ba}=98: 2)$ mixture at $340{ }^{\circ} \mathrm{C}$ (denoted as $\mathrm{Ru} / \mathrm{CaFH}$ ), and $\mathrm{Ru} / \mathrm{CaFH}$ after ammonia synthesis reaction over $30 \mathrm{~h}$ at $340^{\circ} \mathrm{C}$ was examined by $\mathrm{H}_{2}$-TPD (Fig. 2a). The starting temperature for $\mathrm{H}_{2}$ desorption was lowered to the range of room temperature to $50{ }^{\circ} \mathrm{C}$, compared with that for $\mathrm{Ru} / \mathrm{CaH}_{2}$. Supplementary Fig. 4 is the $\mathrm{H}_{2}$-TPD profile of the $\mathrm{Ru}$-deposited $\mathrm{CaF}_{x} \mathrm{H}_{2-x}-\mathrm{CaF}_{2}$ (denoted as $\mathrm{Ru} / \mathrm{CaF}_{x} \mathrm{H}_{2-x}-\mathrm{CaF}_{2}(x$ $=1)$ ), which also indicates that $\mathrm{H}_{2}$ begins to desorb from the material at ca. $50{ }^{\circ} \mathrm{C}$. This implies that the formation of the $\mathrm{CaFH}$ solid solution, i.e., the formation of $\mathrm{Ca}^{2+}-\mathrm{F}^{-}$ionic bonds, clearly weakens the $\mathrm{Ca}^{2+}-\mathrm{H}^{-}$bond and lowers the temperature for the hydrogen release reaction. A notable feature in the $\mathrm{H}_{2}$-TPD profile for $\mathrm{Ru} / \mathrm{CaFH}$ is that it overlaps the $\mathrm{H}_{2}$-TPD profiles of $\mathrm{Ru} /$ $\mathrm{CaH}_{2}$ (Fig. 2a) and $\mathrm{Ru} / \mathrm{CaF}_{x} \mathrm{H}_{2-x}-\mathrm{CaF}_{2}(x=1$ ) (Supplementary Fig. 4). As a result, the $\mathrm{CaFH}$ solid solution may coexist with $\mathrm{CaH}_{2}$ on the surface of $\mathrm{Ru} / \mathrm{CaFH}$.

To evaluate the electron-donating capability of $\mathrm{CaFH}$, the work function of $\mathrm{CaFH}$ with $\mathrm{H}^{-}$vacancies was estimated by densityfunctional theory (DFT) computations ("Methods", Supplementary Fig. 5). The work function on the most stable surface (111) of $\mathrm{CaFH}$ calculated by DFT was $2.2 \mathrm{eV}$, which is smaller than that $(2.7 \mathrm{eV})$ for $\mathrm{CaH}_{2}$ with $\mathrm{H}^{-}$defects because electron repulsion between electrons and $\mathrm{F}^{-}$increases the energy of electrons trapped at $\mathrm{H}^{-}$vacancies. These results indicate that the abstraction of $\mathrm{H}$ atoms from $\mathrm{CaFH}$ forms a strong electrondonating material, which has a work function comparable to that of metallic potassium $(\Phi=2.3 \mathrm{eV})$.

Morphological information for $\mathrm{Ru} / \mathrm{CaFH}$ is summarized in Supplementary Fig. 6. Ru/CaFH with a surface area of $30 \mathrm{~m}^{2} \mathrm{~g}^{-1}$ consists of irregular-shaped particles of $0.5-3 \mu \mathrm{m}$ in diameter. The particle size of $\mathrm{Ru}$ deposited on $\mathrm{CaFH}$ was estimated to be 3-4 nm. XPS measurements for F $1 \mathrm{~s}$ and $\mathrm{Ca} 2 \mathrm{p}$ revealed that the surface atomic ratio of $\mathrm{F}$ to $\mathrm{Ca}(\mathrm{F} / \mathrm{Ca})$ in $\mathrm{Ru} / \mathrm{CaFH}$ was 0.08 , which is much smaller than that expected from $\mathrm{CaF}_{1.0} \mathrm{H}_{1.0}$, and also supports the coexistence of $\mathrm{CaFH}$ and $\mathrm{CaH}_{2}$.

Catalytic performance for ammonia synthesis at low temperatures. The catalytic performance for ammonia formation from $\mathrm{N}_{2}$ and $\mathrm{H}_{2}$ for tested catalysts is summarized in Fig. 3. Figure 3 also contains the results for $\mathrm{CaH}_{2}\left(\mathrm{Ru} / \mathrm{CaH}_{2}\right)$, a $\mathrm{BaH}_{2}-\mathrm{BaO}$ mixture $\left(\mathrm{Ru} / \mathrm{BaH}_{2}-\mathrm{BaO}\right)^{18}$, and Cs-doped $\mathrm{MgO}$ $(\mathrm{Cs}-\mathrm{Ru} / \mathrm{MgO})^{6,10}$ loaded with $\mathrm{Ru}$ nanoparticles, and a commercial $\mathrm{Fe}$ catalyst $^{6}$ for comparison. $\mathrm{Cs}-\mathrm{Ru} / \mathrm{MgO}$ has a higher

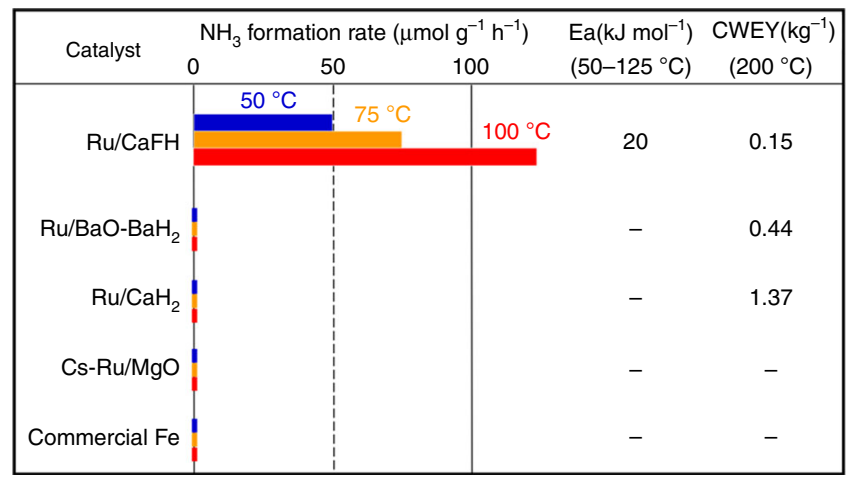

Fig. 3 Catalytic performance. The amounts of loaded $\mathrm{Ru}$ on $\mathrm{Ru} / \mathrm{CaFH}$, Ru/ $\mathrm{BaO}-\mathrm{BaH}_{2}, \mathrm{Ru} / \mathrm{CaH}_{2}$, and $\mathrm{Cs}-\mathrm{Ru} / \mathrm{MgO}$ were $12,10,10$, and $10 \mathrm{wt} \%$, respectively. The catalytic activities of these catalysts at ca. $300^{\circ} \mathrm{C}$ reached the maxima with each $\mathrm{Ru}$ loading. The rates of ammonia formation for $\mathrm{Ru} /$ $\mathrm{CaFH}$ at $50,75,100$, and $125^{\circ} \mathrm{C}$ were $50,75,120$, and $190 \mu \mathrm{mol} \mathrm{g}^{-1} \mathrm{~h}^{-1}$, respectively. CWEYs were estimated from the rates of ammonia formation at each reaction temperature. It was confirmed that the rates of ammonia formation $\left(\mu \mathrm{molh}{ }^{-1}\right.$ ) for $\mathrm{Ru} / \mathrm{CaFH}, \mathrm{Ru} / \mathrm{BaO}-\mathrm{BaH}_{2}$, and $\mathrm{Ru} / \mathrm{CaH}_{2}$ increased in direct ratio to catalyst weight $(0.05-5.00 \mathrm{~g})$.

catalytic activity for ammonia synthesis than the commercial Fe catalyst above $300-400{ }^{\circ} \mathrm{C}$. $\mathrm{Ru} / \mathrm{BaH}_{2}-\mathrm{BaO}$ acts as a highly active ammonia synthesis catalyst ${ }^{18}$ that is comparable with $\mathrm{Ru}$ nanoparticles immobilized on $\mathrm{Ca}\left(\mathrm{NH}_{2}\right)_{2}$ containing $\mathrm{Ba}^{2+}(\mathrm{Ru} / \mathrm{Ba}-\mathrm{Ca}$ $\left.\left(\mathrm{NH}_{2}\right)_{2}\right)$, which exhibits the highest catalytic performance for ammonia synthesis among the reported catalysts over wide temperature $\left(200-450{ }^{\circ} \mathrm{C}\right)$ and pressure ranges $(0.1-0.9 \mathrm{MPa})^{6}$. Supplementary Table 2 shows the physicochemical information (surface area, porosity, and $\mathrm{Ru}$ particle size) and the rates of ammonia formation for $\mathrm{Ru} / \mathrm{CaFH}, \mathrm{Ru} / \mathrm{CaH}_{2}, \mathrm{Ru} / \mathrm{Ba}-\mathrm{Ca}\left(\mathrm{NH}_{2}\right)_{2}$, $\mathrm{Ru} / \mathrm{BaO}-\mathrm{BaH}_{2}, \mathrm{Ru} / \mathrm{C} 12 \mathrm{~A} 7^{19}, \mathrm{Cs}-\mathrm{Ru} / \mathrm{MgO}$, and a commercial Fe catalyst as benchmark catalysts at $100-340^{\circ} \mathrm{C}$. It was confirmed that the catalytic activities of the commercial $\mathrm{Fe}$ catalyst and $\mathrm{Cs}-\mathrm{Ru} / \mathrm{MgO}$ benchmark catalysts were comparable with those reported by other groups ${ }^{19-21}$. These conventional catalysts did not exhibit activity for ammonia synthesis below $100-200^{\circ} \mathrm{C}$, whereas $\mathrm{Ru} / \mathrm{CaFH}$ synthesized ammonia at $50^{\circ} \mathrm{C}$. The ammonia formation over the catalyst at $50^{\circ} \mathrm{C}$ was confirmed by both direct mass spectrometry and ion chromatography, and is not derived from $\mathrm{N}$ species formed on the catalyst during the catalyst activation at $340{ }^{\circ} \mathrm{C}$ (see Supplementary Discussion). The ammonia formation rate of $\mathrm{Ru} / \mathrm{CaFH}$ increased with the temperature and was unchanged even after the rate measurement was repeated, which indicates that $\mathrm{Ru} / \mathrm{CaFH}$ is a stable catalyst. There was no significant difference in XRD pattern between $\mathrm{Ru} / \mathrm{CaFH}$ after reaction and $\mathrm{CaH}_{2}-\mathrm{BaF}_{2}$ mixture heated at $340{ }^{\circ} \mathrm{C}(\mathrm{Ca} / \mathrm{Ba}$ atomic ratio $=98: 2$, Fig. $2 b, c)$. The apparent activation energy for ammonia synthesis over the catalyst in the range of $50-150{ }^{\circ} \mathrm{C}$ was estimated to be $20 \mathrm{~kJ} \mathrm{~mol}^{-1}$, which is less than half that of reported catalysts (from $40 \mathrm{~kJ} \mathrm{~mol}^{-1}$ ) $6,14,18,19,21$. Furthermore, $\mathrm{Ru} / \mathrm{CaFH}$ as a stable catalyst surpasses conventional catalysts at higher temperatures. Figure 3 gives the catalyst weight required for the equilibrium yield (CWEY) of ammonia at $200^{\circ} \mathrm{C}$ (see Supplementary Discussion). The rates of ammonia formation and CWEYs for all tested catalysts, including $\mathrm{Ru} / \mathrm{Ba}-\mathrm{Ca}\left(\mathrm{NH}_{2}\right)_{2}$, and the recently reported highly active catalysts at $200-350{ }^{\circ} \mathrm{C}$ are summarized in Supplementary Table $3^{22-25}$. Although $\mathrm{Ru} / \mathrm{Ba}-\mathrm{Ca}$ $\left(\mathrm{NH}_{2}\right)_{2}$ and $\mathrm{Ru} / \mathrm{BaO}-\mathrm{BaH}_{2}$ have had much smaller CWEYs among the reported highly active catalysts, the CWEY of $\mathrm{Ru} /$ $\mathrm{CaFH}$ was only half that of both catalysts at $200^{\circ} \mathrm{C}$. In the case of $\mathrm{Ru} / \mathrm{CaFH}$, the apparent activation energy $\left(\mathrm{Ea}=20 \mathrm{~kJ} \mathrm{~mol}^{-1}\right)$ 
and coefficient due to the collision frequency $(A=10)$ in the Arrhenius equation estimated from the rates of ammonia formation at $50,75,100$, and $125^{\circ} \mathrm{C}$ were almost the same as those $\left(\mathrm{Ea}=23 \mathrm{~kJ} \mathrm{~mol}^{-1}, \mathrm{~A}=12\right)$ obtained by the ammonia formation rates at $275-340^{\circ} \mathrm{C}$. In addition, there was no significant difference in $\mathrm{Ea}$ and $\mathrm{A}$ for ammonia formation over $\mathrm{Ru} / \mathrm{CaFH}$ at 0.1 and 0.9 MPa. This suggests that the same active sites on $\mathrm{Ru} / \mathrm{CaFH}$ form ammonia through a reaction mechanism in a wide range of reaction conditions $\left(\geq 50^{\circ} \mathrm{C}, \geq 0.1 \mathrm{MPa}\right)$. It was also confirmed in ammonia synthesis $\left(240-400^{\circ} \mathrm{C}\right)$ over a commercial Fe catalyst used in this study that $\mathrm{Ea}$ and $\mathrm{A}$ at $0.1 \mathrm{MPa}$ are identical with those at $0.9 \mathrm{MPa}^{6}$. Furthermore, $\mathrm{Ru} / \mathrm{CaFH}$ produced ammonia without a decrease in activity for long periods of time and at higher temperatures $\left(200\right.$ and $340^{\circ} \mathrm{C}$ ) (Supplementary Figs. 7 and 8 ). Ammonia formation over $\mathrm{Ru} / \mathrm{CaFH}$ was close to the equilibrium yield, even at ca. $300{ }^{\circ} \mathrm{C}$, because of the high catalytic performance. As a result, ammonia synthesis over $\mathrm{Ru} / \mathrm{CaFH}$ in Supplementary Fig. 8 reaches the equilibrium. Despite such equilibrium conversion (i.e., catalyst deactivation test conditions), the rate of ammonia formation over $\mathrm{Ru} / \mathrm{CaFH}$ was constant for over $100 \mathrm{~h}$. The amount of ammonia produced by $\mathrm{Ru} / \mathrm{CaFH}$ at $340{ }^{\circ} \mathrm{C}$ exceeded the amount of the used catalyst (ca. $24 \mathrm{mmol}$ ) within $100 \mathrm{~min}$. The XRD pattern and surface atomic ratio of $\mathrm{F}$ to $\mathrm{Ca}(\mathrm{F} / \mathrm{Ca}=0.08)$ for $\mathrm{Ru} / \mathrm{CaFH}$ were unchanged after reaction for $100 \mathrm{~h}$, which was consistent with the lack of $\mathrm{F}$ species such as HF detected during the reaction. These results are clearly indicative of the stability of the $\mathrm{Ru} / \mathrm{CaFH}$ catalyst.

The surface areas of the supports and ammonia formation rates $\left(340{ }^{\circ} \mathrm{C}\right)$ of $\mathrm{Ru} / \mathrm{CaFH}$, Ru-deposited $\mathrm{BaH}_{2}\left(\mathrm{Ru} / \mathrm{BaH}_{2}\right)$, and $\mathrm{Ru} /$ $\mathrm{CaF}_{x} \mathrm{H}_{2-x}-\mathrm{CaF}_{2}(x=1)$ where $\mathrm{Ru}$ nanoparticles are deposited on the $\mathrm{CaF}_{1.0} \mathrm{H}_{1.0}$ solid solution formed by heating mixtures of orthorhombic $\mathrm{CaH}_{2}$ and cubic $\mathrm{CaF}_{2}$ at $550{ }^{\circ} \mathrm{C}$ are summarized in Supplementary Table $4 . \mathrm{BaH}_{2}$ and $\mathrm{CaF}_{1.0} \mathrm{H}_{1.0}$ solid solution are expected to be formed on $\mathrm{Ru} / \mathrm{CaFH}$, and either or both of them can contribute to the catalytic performance of $\mathrm{Ru} / \mathrm{CaFH}$. However, $\mathrm{Ru} / \mathrm{BaH}_{2}$ had a much smaller catalytic activity for ammonia synthesis than $\mathrm{Ru} / \mathrm{CaF}_{x} \mathrm{H}_{2-x}-\mathrm{CaF}_{2}(x=1)$, which indicates that the catalysis of $\mathrm{Ru} / \mathrm{CaFH}$ is derived from the $\mathrm{CaF}_{1.0} \mathrm{H}_{1.0}$ solid solution. Supplementary Table 4 also shows $\mathrm{Ru} / \mathrm{CaF}_{x} \mathrm{H}_{2-x}-\mathrm{CaF}_{2}$ $(x=1)$ to be inferior to $\mathrm{Ru} / \mathrm{CaFH}$ with respect to ammonia synthesis. This can be attributed to the conventional preparation method for the $\mathrm{CaF}_{1.0} \mathrm{H}_{1.0}$ solid solution. $\mathrm{Ru} / \mathrm{CaF}_{x} \mathrm{H}_{2-x}-\mathrm{CaF}_{2}(x=$ 1) was prepared by the deposition of $\mathrm{Ru}$ nanoparticles. $\mathrm{CaF}_{x} \mathrm{H}_{2-}$ ${ }_{x}-\mathrm{CaF}_{2} \quad(x=1)$ synthesized by high-temperature solid-state reaction at $\geq 550^{\circ} \mathrm{C}$ for $20 \mathrm{~h}$ and the resultant surface area was very small $\left(1 \mathrm{~m}^{2} \mathrm{~g}^{-1}\right)$, which limits the catalytic activity of $\mathrm{Ru} /$ $\mathrm{CaF}_{x} \mathrm{H}_{2-x}-\mathrm{CaF}_{2}(x=1)$. On the other hand, in the case of $\mathrm{CaFH}$ prepared by the new method, $\mathrm{CaFH}$ solid solution was formed on the surface with a surface area of $10 \mathrm{~m}^{2} \mathrm{~g}^{-1}$. This is considered to be the reason for the difference in activity between $\mathrm{Ru} / \mathrm{CaFH}$ and $\mathrm{Ru} / \mathrm{CaF}_{x} \mathrm{H}_{2-x}-\mathrm{CaF}_{2}(x=1)$.

Electron-donating capability and reaction mechanism of $\mathbf{R u}$ / CaFH. Ammonia synthesis from $\mathrm{N}_{2}$ and $\mathrm{D}_{2}$ over $\mathrm{Ru} / \mathrm{CaFH}$ was examined to clarify the reaction mechanism. $\mathrm{Ru} / \mathrm{CaFH}$ prepared at $340{ }^{\circ} \mathrm{C}$ in a flow of $\mathrm{H}_{2}$ alone was cooled down from $340{ }^{\circ} \mathrm{C}$ to $180^{\circ} \mathrm{C}$ in a flow of $\mathrm{Ar}$, and then $\mathrm{N}_{2}-\mathrm{D}_{2}$ was passed into $\mathrm{Ru} / \mathrm{CaFH}$ at temperature under atmospheric pressure (see "Methods"). The experimental reaction time profiles for ammonia synthesis from $\mathrm{N}_{2}$ and $\mathrm{D}_{2}$ over $\mathrm{Ru} / \mathrm{CaFH}$ are shown in Fig. 4. Soon after an increase in the $m / z=17$ signal $\left(\mathrm{NH}_{3}\right.$ and $\mathrm{NDH}$ as fragments of $\mathrm{ND}_{2} \mathrm{H}$ and $\left.\mathrm{NDH}_{2}\right)$, the signal of $m / z=18\left(\mathrm{NDH}_{2}\right.$ and $\mathrm{ND}_{2}$ as a fragment of $\left.\mathrm{ND}_{3}\right)$ increased. The $m / z=19\left(\mathrm{ND}_{2} \mathrm{H}\right)$ signal was observed after ca. $3 \mathrm{~min}$ from the introduction of $\mathrm{N}_{2}-\mathrm{D}_{2}$. The fragment ratio of $m / z=17\left(\mathrm{NH}_{3}\right), 16\left(\mathrm{NH}_{2}\right)$, and $15(\mathrm{NH})$ in

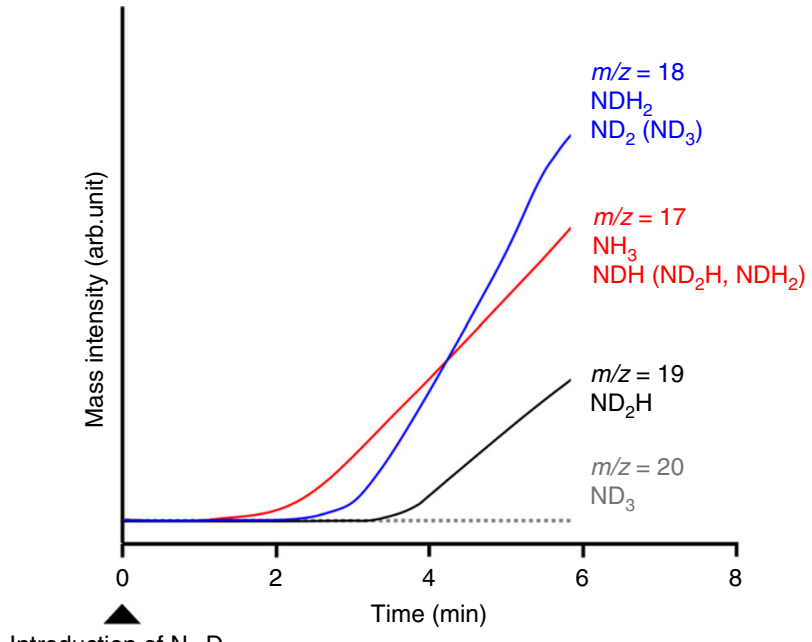

Introduction of $\mathrm{N}_{2}-\mathrm{D}_{2}$

Fig. 4 Time courses of ammonia synthesis from $\mathrm{N}_{\mathbf{2}}$ and $\mathrm{D}_{\mathbf{2}}$ over $\mathrm{Ru} / \mathrm{CaFH}$. Reaction time profiles at the early stage of ammonia synthesis from $\mathrm{N}_{2}$ and $\mathrm{D}_{2}$ over $\mathrm{Ru} / \mathrm{CaFH}$ at $180^{\circ} \mathrm{C}$.

pure $\mathrm{NH}_{3}$ was ca. 100:80:8, so that each fragment intensity did not exceed the parent intensity. The formation of $\mathrm{ND}_{3}(\mathrm{~m} / z=20)$ was not observed within $10 \mathrm{~min}$ from the beginning of the reaction. As a result, $\mathrm{NH}_{3}$ was first formed, followed by the formation of $\mathrm{NDH}_{2}$ and $\mathrm{ND}_{2} \mathrm{H}$; ammonia species containing $\mathrm{H}$ was formed at the early stage of ammonia synthesis from $\mathrm{N}_{2}$ and $\mathrm{D}_{2}$ over $\mathrm{Ru} / \mathrm{CaFH}$. These results indicate that $\mathrm{H}$ in the $\mathrm{CaFH}$ bulk is used for ammonia formation at the early stage of reaction, and $\mathrm{H}$ can move from $\mathrm{CaFH}$ bulk to the $\mathrm{Ru}$ surface to react with $\mathrm{N}$ adatoms. The same phenomenon had been observed on $\mathrm{Ru}$ nanoparticle-deposited $\mathrm{Ca}_{2} \mathrm{NH}$ (calcium nitride hydride) ${ }^{14}$.

$\mathrm{XPS} \mathrm{Ru} 3 \mathrm{p}_{3 / 2}$ of $\mathrm{Ru} / \mathrm{CaFH}$ was used to evaluate the electrondonating capability from $\mathrm{CaFH}$ to $\mathrm{Ru}$ (Supplementary Fig. 9). Ru $3 p_{3 / 2}$ for $\mathrm{Ru} / \mathrm{CaFH}$ appeared at a slightly lower binding energy than that for metallic $\mathrm{Ru}$ particles deposited on $\mathrm{SiO}_{2}\left(\mathrm{Ru} / \mathrm{SiO}_{2}\right)$, which indicates that $\mathrm{Ru}$ on $\mathrm{CaFH}$ is more negative than $\mathrm{Ru}$ on $\mathrm{SiO}_{2}$. However, the difference was not so large, because XPS reflects only $\mathrm{Ru}$ atoms near the edges of $\mathrm{Ru}$ particles connected to $\mathrm{CaFH}$ from the point of view of the escape depth of photoelectrons. For this reason, we have adopted Fourier transform- infrared (FT-IR) spectroscopy measurements using $\mathrm{N}_{2}$ as a probe molecule, which is a more sensitive method (FT-IR, Fig. 5). Figure $5 \mathrm{a}$ measured at $25^{\circ} \mathrm{C}$ showed $\mathrm{N} \equiv \mathrm{N}$ stretching $\left(v \mathrm{~N}_{2}\right)$ bands of $\mathrm{N}_{2}$ adsorbed on $\mathrm{Ru} / \mathrm{CaH}_{2}$ at $2100-2250 \mathrm{~cm}^{-1}$, lower than that of gaseous $\mathrm{N}_{2}\left(2744 \mathrm{~cm}^{-1}\right)$, which indicated that the electron donation from the catalyst to the antibonding $\pi^{*}$ orbitals of adsorbed $\mathrm{N}_{2}$ via $\mathrm{Ru}$ d-orbitals (i.e., back donation) weakens the $\mathrm{N} \equiv \mathrm{N}$ bond. The $v \mathrm{~N}_{2}$ bands have been reported to appear at $2100-2300 \mathrm{~cm}^{-1}$ in highly active catalysts for ammonia synthesis ${ }^{19,26}$. However, these catalysts cannot function at low temperatures; such electron donation capability is insufficient to realize low-temperature ammonia synthesis. In the case of $\mathrm{Ru} /$ $\mathrm{CaFH}, v \mathrm{~N}_{2}$ was observed in the range of $2030-2150 \mathrm{~cm}^{-1}$, which is much lower than that reported for efficient catalysts, including $\mathrm{Ru} / \mathrm{CaH}_{2}$. This can be clearly attributed to the high electrondonating capability of $\mathrm{Ru} / \mathrm{CaFH}$ at room temperature. $\mathrm{H}_{2}-\mathrm{TPD}$ (Fig. 2a) and DFT experiments revealed that the abstraction of $\mathrm{H}$ atoms from $\mathrm{CaFH}$ by $\mathrm{Ru}$ forms $\mathrm{CaFH}$ with $\mathrm{H}^{-}$defects trapping electrons at $\mathrm{ca} .50^{\circ} \mathrm{C}$, resulting in strong electron-donating power. Supplementary Fig. 10 shows an FT-IR spectrum $\left(1550-1700 \mathrm{~cm}^{-1}\right)$ for $\mathrm{N}$-adsorbed $\mathrm{Ru} / \mathrm{CaFH}$ at $25^{\circ} \mathrm{C}\left(\mathrm{N}_{2}\right.$ : $12 \mathrm{kPa}$ ) and a band assignable to $\delta \mathrm{NH}$ bending, which can be attributed to adsorbed ammonia from the broad band at ca. 

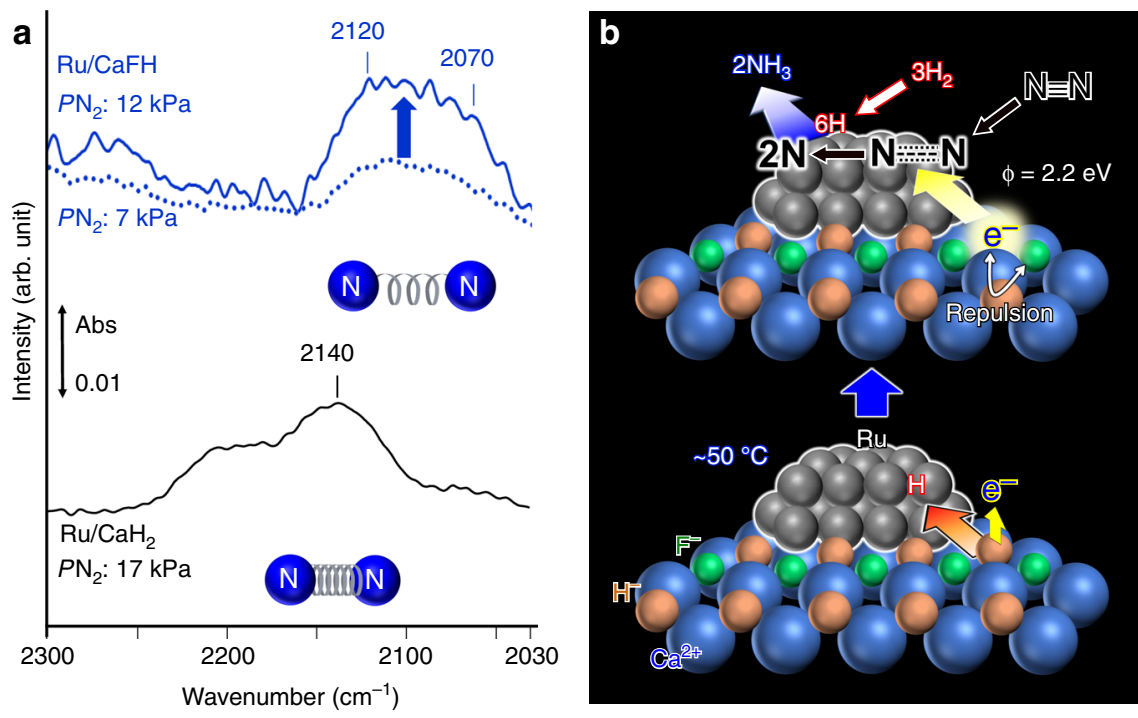

Fig. 5 FT-IR spectra and a possible reaction mechanism. a FT-IR spectra for $\mathrm{N}_{2}$ adsorption on $\mathrm{Ru} / \mathrm{CaFH}$ and $\mathrm{Ru} / \mathrm{CaH}$ after ammonia synthesis reaction at $340^{\circ} \mathrm{C}$, followed by cooling down below $20^{\circ} \mathrm{C}$. The FT-IR spectra were measured according to previous reports ${ }^{19}$. $\mathrm{N}_{2}$ was adsorbed on the catalysts at $25^{\circ} \mathrm{C}$ in the presence of $\mathrm{N}_{2}(6-15 \mathrm{kPa}) . \mathrm{N} \equiv \mathrm{N}$ stretching $\left(\mathrm{\nu N}_{2}\right)$ bands were not observed in both catalysts under vacuum. b Proposed reaction mechanism.

$1600 \mathrm{~cm}^{-1}$. This indicates that $\mathrm{N}_{2}$ molecules are dissociated into $\mathrm{N}$ adatoms, which react with $\mathrm{H}$ from $\mathrm{CaFH}$ even at $25^{\circ} \mathrm{C}$, and is consistent with the $\mathrm{H}_{2}$-TPD results and ammonia synthesis from $\mathrm{N}_{2}$ and $\mathrm{D}_{2}$

To summarize these results, Fig. $5 \mathrm{~b}$ shows a proposed reaction mechanism. In $\mathrm{Ru} / \mathrm{CaFH}$ where a (111) surface is probably formed in the $\mathrm{CaFH}$ solid solution due to its stability, the bond strength of $\mathrm{Ca}-\mathrm{F}$ surpasses that of $\mathrm{Ca}-\mathrm{H}$, which weakens $\mathrm{Ca}-\mathrm{H}$ bonds in the $\mathrm{CaFH}$ solid solution, so that $\mathrm{Ru}$ can abstract $\mathrm{H}$ atoms from $\mathrm{H}^{-}$sites in $\mathrm{CaFH}$ to leave electrons $\left(\mathrm{e}^{-}\right)$in these sites, even at ca. $50^{\circ} \mathrm{C}$. The resultant $\mathrm{CaFH}$ with $\mathrm{H}^{-}$vacancies that trap $\mathrm{e}^{-}$behaves as a surface electride with a small work function $(\Phi=2.2 \mathrm{eV})$ that is much smaller than that of $\mathrm{CaH}_{2}(2.7 \mathrm{eV})$ and comparable with that of metallic potassium $(2.3 \mathrm{eV})$. This high electron-donating capability originates from the strong electron repulsion between $\mathrm{e}^{-}$in the $\mathrm{H}^{-}$and $\mathrm{F}^{-}$vacancies, which significantly enhances electron donation from the electride to the $\pi^{*}$ orbitals of $\mathrm{N}_{2}$ molecules through the $3 \mathrm{~d}$ orbitals of $\mathrm{Ru}$. This facilitates the dissociative adsorption of $\mathrm{N}_{2}$, which results in ammonia formation at low temperatures.

\section{Methods}

Preparation of $\mathbf{C a H}_{\mathbf{2}}-\mathbf{B a F}_{\mathbf{2}}$ mixture and $\mathbf{R u} / \mathbf{C a F H}$. First, a mixture of $87 \mathrm{~mol} \%$ $\mathrm{BaF}_{2}$ (Wako Chemicals) and $13 \mathrm{~mol} \% \mathrm{BaH}_{2}$ (Stream Chemicals) was heated at $400{ }^{\circ} \mathrm{C}$ for $10 \mathrm{~h}$ in a flow of $\mathrm{Ar}\left(15 \mathrm{~mL} \mathrm{~min}^{-1}\right)$ to put large and rigid $\mathrm{BaF}_{2}$ particles into disorder. The XRD pattern of the resulting material (modified $\mathrm{BaF}_{2}$ ) consisted of broad diffraction peaks due to $\mathrm{BaF}_{2}$ (Supplementary Fig. 11). No diffraction peaks due to $\mathrm{BaH}_{2}$ were observed in the XRD pattern of modified $\mathrm{BaF}_{2}$. Next, a simple mixture of $\mathrm{CaH}_{2}$ (Sigma-Aldrich) and the resulting modified $\mathrm{BaF}_{2}$ powders $\left(\mathrm{Ca} / \mathrm{Ba}\right.$ atomic ratios of $98: 2,9: 1,5: 1$, and $3: 1$ ) was heated at $340{ }^{\circ} \mathrm{C}$ for $10 \mathrm{~h}$ in a flow of $\mathrm{H}_{2}\left(2.5 \mathrm{~mL} \mathrm{~min}^{-1}\right)$.

$\mathrm{Ru} / \mathrm{CaFH}$ was prepared by two methods based on chemical vapor deposition using ruthenium acetylacetonate $\left(\mathrm{Ru}(\mathrm{acac})_{3}\right)$. In Method 1 , the resulting material $(\mathrm{Ca} / \mathrm{Ba}$ atomic ratios of $98: 2)$ obtained by the above procedure was heated with $\mathrm{Ru}$ (acac) ${ }_{3}$ (Sigma-Aldrich) for deposition of $12 \mathrm{wt} \% \mathrm{Ru}$ at $260{ }^{\circ} \mathrm{C}$ for $2 \mathrm{~h}$ and at $340{ }^{\circ} \mathrm{C}$ for $10 \mathrm{~h}$ in a flow of $\mathrm{H}_{2}\left(2.5 \mathrm{~mL} \mathrm{~min}^{-1}\right)$. In Method 2, $\mathrm{Ru}$ nanoparticles were loaded onto a mixture of $\mathrm{CaH}_{2}$ and $\mathrm{BaF}_{2}$ by chemical vapor deposition using $\mathrm{Ru}(\mathrm{acac})_{3}$ for deposition of $12 \mathrm{wt} \% \mathrm{Ru}$. The mixture of $98 \mathrm{~mol} \% \mathrm{CaH}_{2}, 2 \mathrm{~mol} \%$ modified $\mathrm{BaF}_{2}$, and $\mathrm{Ru}(\mathrm{acac})_{3}$ corresponding to $12 \mathrm{wt} \% \mathrm{Ru}$ was heated at $260{ }^{\circ} \mathrm{C}$ for $2 \mathrm{~h}$ and at $340{ }^{\circ} \mathrm{C}$ for $10 \mathrm{~h}$ in a flow of $\mathrm{H}_{2}\left(2.5 \mathrm{~mL} \mathrm{~min}{ }^{-1}\right)$. There was no significant difference in ammonia synthetic activity and structure between the catalysts prepared by both methods. The results for the catalyst prepared by simple Method 2 are shown in this paper.
Preparation of solid solution $\mathrm{CaF}_{x} \mathrm{H}_{2-x}-\mathrm{CaF}_{2}$ and $\mathrm{Ru} / \mathrm{CaF}_{x} \mathrm{H}_{2-x}-\mathrm{CaF}_{2}$. Appropriate amounts of $\mathrm{CaF}_{2}$ (Wako Chemicals) and $\mathrm{CaH}_{2}$ were mixed by grinding, and the mixture was heated at $550^{\circ} \mathrm{C}$ for $20 \mathrm{~h}$ in a flow of $\mathrm{Ar}\left(15 \mathrm{~mL} \mathrm{~min}{ }^{-1}\right)$, which resulted in $\mathrm{CaF}_{\mathrm{x}} \mathrm{H}_{2-\mathrm{x}}$ solid solutions $(1.0 \leq x \leq 1.6) . \mathrm{Ru} / \mathrm{CaF}_{x} \mathrm{H}_{2-x}-\mathrm{CaF}_{2}(x=1)$ was prepared by heating $\mathrm{CaF}_{x} \mathrm{H}_{2-x}-\mathrm{CaF}_{2}(x=1)$ and $\mathrm{Ru}(\mathrm{acac})_{3}$ corresponding to $12 \mathrm{wt}$ $\% \mathrm{Ru}$ at $260^{\circ} \mathrm{C}$ in a flow of $\mathrm{H}_{2}\left(2.5 \mathrm{~mL} \mathrm{~min}^{-1}\right)$. After $2 \mathrm{~h}$, the sample was heated at $340^{\circ} \mathrm{C}$ for $10 \mathrm{~h}$ in the $\mathrm{H}_{2}$ flow.

Preparation of $\mathbf{R u} / \mathrm{CaH}_{2}, \mathbf{R u} / \mathrm{BaH}_{2}$, and $\mathbf{R u} / \mathrm{BaH}_{2}-\mathrm{BaO}$. According to previous reports ${ }^{18}, \mathrm{Ru} / \mathrm{CaH}_{2}, \mathrm{Ru} / \mathrm{BaH}_{2}$, and $\mathrm{Ru} / \mathrm{BaH}_{2}-\mathrm{BaO}$ were prepared by heating $\mathrm{CaH}_{2}, \mathrm{BaH}_{2}$, and a mixture of $3 \mathrm{~mol} \% \mathrm{BaO}$ (Kojundo Chemical) and $97 \mathrm{~mol} \% \mathrm{CaH}_{2}$, respectively, with $\mathrm{Ru}(\mathrm{acac})_{3}$ corresponding to $10 \mathrm{wt} \% \mathrm{Ru}$ at $260{ }^{\circ} \mathrm{C}$ in a flow of $\mathrm{H}_{2}\left(2.5 \mathrm{~mL} \mathrm{~min}^{-1}\right)$. After $2 \mathrm{~h}$, the samples were heated at $340^{\circ} \mathrm{C}$ for $10 \mathrm{~h}$ in the $\mathrm{H}_{2}$ flow. The activities of both catalysts for ammonia synthesis increased with the $\mathrm{Ru}$ loading and reached their respective maximum at a loading of $10 \mathrm{wt}$ $\% \mathrm{Ru}$.

Preparation of Cs-Ru/MgO. Cs- $\mathrm{Ru} / \mathrm{MgO}$ was prepared according to previous reports ${ }^{2} . \mathrm{MgO}$ (Ube, 500A) was heated in high vacuum at $500{ }^{\circ} \mathrm{C}$ for $6 \mathrm{~h}$ and then stirred in a solution of $\mathrm{Ru}_{3}(\mathrm{CO})_{12}$ in THF for $4 \mathrm{~h}$ at room temperature. After evaporating the solvent, the obtained powder was slowly heated to $450{ }^{\circ} \mathrm{C}$ in high vacuum to decompose the carbonyl precursor. The amount of $\mathrm{Ru}$ loading was $10 \mathrm{wt} \%$. After the obtained gray powder was stirred in a solution of $\mathrm{Cs}_{2} \mathrm{CO}_{3}$ in dehydrated ethanol for $3 \mathrm{~h}$, the solvent was evaporated. The resulting catalyst was dried in vacuum. The catalytic activity of $\mathrm{Cs}-\mathrm{Ru} / \mathrm{MgO}$ reached a maximum at loading of $10 \mathrm{wt} \% \mathrm{Ru}$.

Evaluation of catalytic performance. Typical ammonia synthesis was conducted in a silica-glass fixed-bed reactor (catalyst: $0.1 \mathrm{~g}$ ) in a flow of $\mathrm{N}_{2}-\mathrm{H}_{2}\left(\mathrm{~N}_{2}: \mathrm{H}_{2}=1: 3\right.$, $60 \mathrm{~mL} \mathrm{~min}^{-1}$, weight hourly space velocity (WHSV): $36,000 \mathrm{~mL} \mathrm{gcat}^{-1} \mathrm{~h}^{-1}$ ) under atmospheric pressure $(0.1 \mathrm{MPa})$. First, ammonia synthesis over each tested catalyst was conducted at $340{ }^{\circ} \mathrm{C}$ under the specified reaction conditions. When no increase or decrease in activity was observed for over $30 \mathrm{~h}$, the catalyst was cooled down below $20^{\circ} \mathrm{C}$ in a flow of $\mathrm{N}_{2}$ at a flow rate of $60 \mathrm{~mL} \mathrm{~min}^{-1}$ and then held under this flow for $5 \mathrm{~h}$. After no ammonia was detected, the catalyst was heated at specific temperatures in a flow of $\mathrm{N}_{2}-\mathrm{H}_{2}\left(\mathrm{~N}_{2}: \mathrm{H}_{2}=5: 1,60 \mathrm{~mL} \mathrm{~min}^{-1}\right)$. Ammonia was analyzed by both direct mass spectrometry (BELMass, MicrotracBEL, Japan) and ion chromatography. There was no difference in ammonia formation rate between both methods. In the case of ion chromatography, the ammonia produced was trapped in $5 \mathrm{mM} \mathrm{H}_{2} \mathrm{SO}_{4}$ aqueous solution, and the amount of $\mathrm{NH}_{4}{ }^{+}$generated in the solution was estimated using an ion chromatograph (LC-2000 plus, Jasco) equipped with a conductivity detector. The rate of ammonia formation was repeatedly measured more than three times after the ammonia formation rate remained constant for over $1 \mathrm{~h}$. It was verified that the measured rate had an error of less than $10 \%$. There was no difference in ammonia formation rate between direct mass spectrometry and ion chromatography. 
Ammonia synthesis from $\mathbf{N}_{\mathbf{2}}$ and $\mathbf{D}_{\mathbf{2}}$. A mixture of $98 \mathrm{~mol} \% \mathrm{CaH}_{2}, 2 \mathrm{~mol} \%$ modified $\mathrm{BaF}_{2}$, and $\mathrm{Ru}(\mathrm{acac})_{3}$ corresponding to $12 \mathrm{wt} \% \mathrm{Ru}$ was heated in the reactor at $260^{\circ} \mathrm{C}$ for $2 \mathrm{~h}$ and at $300^{\circ} \mathrm{C}$ for $10 \mathrm{~h}$ in a flow of $\mathrm{H}_{2}\left(2.5 \mathrm{~mL} \mathrm{~min}^{-1}\right)$. The resultant $\mathrm{Ru} / \mathrm{CaFH}$ was cooled down from that temperature to $180^{\circ} \mathrm{C}$ in a flow of Ar at a flow rate of $2.5 \mathrm{~mL} \mathrm{~min}^{-1}$ and held under this flow for $5 \mathrm{~h}$. After each mass signal intensity was kept constant, $\mathrm{N}_{2}-\mathrm{D}_{2}\left(\mathrm{~N}_{2}: 5 \mathrm{~mL} \mathrm{~min}^{-1}, \mathrm{D}_{2}: 15 \mathrm{~mL} \mathrm{~min}^{-1}\right)$ was passed into $\mathrm{Ru} / \mathrm{CaFH}$ at that temperature under atmospheric pressure. The outlet gas from the reactor was analyzed using mass spectrometry (BELMass, MicrotracBEL, Japan).

Characterization. XRD (D8 Advance, Bruker) patterns were obtained using $\mathrm{Cu} \mathrm{Ka}$ radiation. Nitrogen adsorption-desorption isotherms were measured at $-196^{\circ} \mathrm{C}$ with a surface-area analyzer (BELSORP-mini II, MicrotracBEL) to estimate the Brunauer-Emmett-Teller (BET) surface areas. The morphology of the samples was examined using scanning electron microscopy (SEM, S-5500, Hitachi) equipped with an energy-dispersive X-ray spectroscopy (EDX, EMAX EX-250, Horiba) detector. The microstructural characteristics of the samples were determined from transmission electron microscopy (TEM, JEM-ARM $200 \mathrm{~F}$, Jeol) observations. $\mathrm{H}_{2}$ TPD measurements were conducted by heating $\left(1^{\circ} \mathrm{C} \mathrm{min}^{-1}\right)$ a sample (ca. $100 \mathrm{mg}$ ) in a stream of $\operatorname{Ar}\left(30 \mathrm{~mL} \mathrm{~min}^{-1}\right)$, and monitoring of the concentration of $\mathrm{H}_{2}$ with a thermal conductivity detector (TCD) and a mass spectrometer (BELMass,

MicrotracBEL, Japan). FT-IR spectroscopy measurements of adsorbed $\mathrm{N}_{2}$ were conducted using a spectrometer (FT/IR-6100, Jasco) equipped with a mercury-cadmium-tellurium detector at a resolution of $4 \mathrm{~cm}^{-1}$. Samples were pressed into self-supported disks. A disk was placed in a sealed and Ar-filled silicaglass cell equipped with $\mathrm{NaCl}$ windows to a closed gas-circulation system to allow thermal adsorption-desorption experiments. The disk was heated under vacuum at $200{ }^{\circ} \mathrm{C}$ for $90 \mathrm{~min}$. After the pretreatment, the disk was cooled to $25^{\circ} \mathrm{C}$ under vacuum to obtain a background spectrum from the spectra of the $\mathrm{N}_{2}$-adsorbed samples. Pure $\mathrm{N}_{2}(99.99995 \%)$ was supplied to the system through a liquidnitrogen trap. In all, $12 \mathrm{wt} \% \mathrm{Ru} / \mathrm{CaH}_{2}$ and $12 \mathrm{wt} \% \mathrm{Ru} / \mathrm{CaFH}$ were used for FT-IR measurements. XPS (ESCA-3200, Shimadzu, Mg K $\alpha, 8 \mathrm{kV}, 25 \mathrm{~mA}$ ) was performed in conjunction with an Ar-filled glovebox. The samples were moved to the ultrahigh-vacuum (UHV) XPS apparatus through the Ar-filled glovebox without exposure to the ambient air. The binding energy was corrected with respect to the $\mathrm{Au} 4 \mathrm{f}_{7 / 2}$ peak of $\mathrm{Au}$-deposited samples.

DFT computations. The work functions of near-surface ions were calculated using the slab supercell model on the (111) plane, which is the most experimentally (cleavage plane) and theoretically (smallest surface energy) stable plane for fluorite crystals. The slabs were constructed by relaxing a bulk unit cell of cubic $\mathrm{CaFH}$ $(5.465 \mathrm{~A})^{17}$ and then stacking up the relaxed cell to form a slab. The slab was repeated periodically in the [111] direction with a vacuum gap of $>20 \AA$ to form a supercell. Surface relaxation was taken into account by further relaxation of the two layers on each surface of the slabs. Relaxation was terminated when the force on each atom became less than $0.01 \mathrm{eV}^{-1}$. All the slab calculations were performed with a cut-off energy of $500 \mathrm{eV}$ and a $\mathrm{k}$ mesh of $2 \times 2 \times 1$. The slab thickness was varied between seven and ten layers to ascertain convergence with respect to thickness. The band structures for $\mathrm{CaFH}(111)$ solid solutions with $\mathrm{H}^{-}$or $\mathrm{F}^{-}$ defects $\left(\mathrm{CaFH}_{1-x}, \mathrm{CaF}_{1-x} \mathrm{H}\right)$ were computed in this study. The results are shown in Supplementary Fig. 5. The work function of $\mathrm{CaFH}_{1-x}$ was identical to that of $\mathrm{CaF}_{1-x} \mathrm{H}$, and was estimated to be $2.2 \mathrm{eV}$. This value is smaller than that for $\mathrm{CaH}_{2}$ $(2.7 \mathrm{eV})$, which suggests that fluorine with a larger electronegativity pushes the energy level of electrons up by electrostatic repulsion.

\section{Data availability}

All relevant data that support the findings of this study are presented in the paper and supporting information. Source data are available from the corresponding author upon reasonable request.

Received: 6 November 2019; Accepted: 1 April 2020;

Published online: 24 April 2020

\section{References}

1. Song, P., Kang, L., Wang, H., Guo, R. \& Wang, R. Nitrogen (N), phosphorus (P)-codoped porous carbon as a metal-free electrocatalyst for $\mathrm{N}_{2}$ reduction under ambient conditions. ACS Appl. Mater. Interfaces 11, 12408-12414 (2019).

2. Hara, M., Kitano, M. \& Kamata, K. Ru-loaded C12A7: $\mathrm{e}^{-}$electride as a catalyst for ammonia synthesis. ACS Catal. 7, 2312-2324 (2017).

3. Morgan, E. R., Manwell, J. F. \& McGowan, J. G. Sustainable ammonia production from U.S. offshore wind farms: a techno economic review. ACS Sustain. Chem. Eng. 5, 9554-9567 (2017).

4. Yandulov, D. V. \& Schrock, R. R. Catalytic reduction of dinitrogen to ammonia at a single molybdenum center. Science 301, 76-78 (2003).
5. Arashida, K., Miyake, Y. \& Nishibayashi, Y. A molybdenum complex bearing PNP-type pincer ligands leads to the catalytic reduction of dinitrogen into ammonia. Nat. Chem. 3, 120-125 (2011).

6. Kitano, M. et al. Self-organized ruthenium-barium core-shell nanoparticles on a mesoporous calcium amide matrix for efficient low-temperature ammonia synthesis. Angew. Chem. 130, 2678-2682 (2018).

7. Lin, B., Wei, K., Ma, X., Lin, J. \& Ni, J. Study of potassium promoter effect for $\mathrm{Ru} / \mathrm{AC}$ catalysts for ammonia synthesis. Catal. Sci. Technol. 3, 1367-1374 (2013).

8. Dietrich, H., Jacobi, K. \& Etrl, G. Vibrational analysis of the $\mathrm{NH}+\mathrm{N}$ coadsorbate on Ru (0001). Surf. Sci. 377-379, 308-312 (1997).

9. Strongin, D. R. \& Somorjai, G. A. The effects of potassium on ammonia synthesis over iron single-crystal surfaces. J. Catal. 109, 51-60 (1988).

10. Aika, K., Takano, T. \& Murata, S. Preparation and characterization of chlorinefree ruthenium catalysts and the promoter effect in ammoniasynthesis. 3. A magnesia-supported ruthenium catalyst. J. Catal. 136, 126-140 (1992).

11. Rosowski, F., Hornung, A., Hinrichsen, O., Herein, D., Muhler, M. \& Ertl, G. Ruthenium catalysts for ammonia synthesis at high pressures: preparation, characterization, and power-law kinetics. Appl. Catal. A 151, 443-460 (1997).

12. Harle, H., Mendel, K., Metka, U., Volpp, H. R., Willms, L. \& Wolfrum, J. Temperature dependence $(90-440 \mathrm{~K})$ of the vibrational spectra of CO adsorbed on Platinum (111) studied by sum-frequency generation. Chem. Phys. Lett. 279, 275-281 (1997).

13. Carlsson, A. F., Baumer, M., Risse, T. \& Freund, H. J. Surface structure of Co-Pd bimetallic particles supported on thin films studied using infrared reflection absorption spectroscopy of CO. J. Chem. Phys. 119, 10885-10894 (2003).

14. Kitano, M. et al. Essential role of hydride ion in ruthenium-based ammonia synthesis catalysts. Chem. Sci. 7, 4036-4043 (2016).

15. Ong, P. V., Johnson, L. E., Hosono, H. \& Sushko, P. V. Structure and stability of $\mathrm{CaH}_{2}$ surfaces: on the possibility of electron-rich surfaces in metal hydrides for catalysis. J. Mater. Chem. A 5, 5550-5558 (2017).

16. Luo, Y. R. Comprehensive Handbook of Chemical Bond Energies (CRC Press, Boca Raton, FL, 2007).

17. Mizoguchi, H. et al. Cubic fluorite-type $\mathrm{CaH}_{2}$ with a small bandgap. J. Am . Chem. Soc. 139, 11317-11320 (2017).

18. Hattori, M. et al. Enhanced catalytic ammonia synthesis with transformed BaO. ACS Catal. 8, 10977-10984 (2018).

19. Kitano, M. et al. Ammonia synthesis using a stable electride as an electron donor and reversible hydrogen store. Nat. Chem. 4, 934-940 (2012).

20. Liu, H., Nian, X. \& Hu, Z. Development of novel low temperature and low pressure ammonia synthesis catalyst. Appl. Catal. Gen. 142, 209-222 (1996).

21. Sato, K. et al. A low-crystalline ruthenium nano-layer supported on praseodymium oxide as an active catalyst for ammonia synthesis. Chem. Sci. 8 , 674-679 (2017).

22. Wang, P. K. et al. Breaking scaling relations to achieve low-temperature ammonia synthesis through $\mathrm{LiH}$-mediated nitrogen transfer and hydrogenation. Nat. Chem. 9, 64-70 (2017).

23. Gao, W. B. et al. Barium hydride-mediated nitrogen transfer and hydrogenation for ammonia synthesis: a case study of cobalt. ACS Catal. 7, 3654-3661 (2017).

24. Ogura, Y. et al. Efficient ammonia synthesis over a $\mathrm{Ru} / \mathrm{La}_{0.5} \mathrm{Ce}_{0.5} \mathrm{O}_{1.75}$ catalyst pre-reduced at high temperature. Chem. Sci. 9, 2230-2237 (2018).

25. Ogura, Y. et al. $\mathrm{Ru} / \mathrm{La}_{0.5} \mathrm{Pr}_{0.5} \mathrm{O}_{1.75}$ catalyst for low-temperature ammonia synthesis. ACS Sustain. Chem. Eng. 6, 17258-17266 (2018).

26. Kubota, J. \& Aika, K. Infrared studies of adsorbed dinitrogen on supported ruthenium catalysts for ammonia synthesis: effects of the alumina and magnesia supports and the cesium compound promoter. J. Phys. Chem. 98, 11293-11300 (1994).

\section{Acknowledgements}

This work was supported by a fund from the Grants-in-Aid for Japan Society for the Promotion of Science (JSPS) Fellows and for Scientific Research from the Ministry of Education, Culture, Science, Sports, and Technology (MEXT) of Japan (19K15358, $18 \mathrm{H} 05251$, and 17H06153).

\section{Author contributions}

M. Hattori designed the study, carried out catalyst synthesis, its evaluation, and mechanistic study, and composed the paper. S.I. performed catalyst evaluation and characterization. T.N. performed DFT computation. M. Hara and H.H. supervised the study, planned the experiments, and analyzed the data.

\section{Competing interests}

The authors declare no competing interests. 


\section{Additional information}

Supplementary information is available for this paper at https://doi.org/10.1038/s41467020-15868-8

Correspondence and requests for materials should be addressed to H.H. or M.H.

Peer review information Nature Communications thanks the anonymous reviewers for their contribution to the peer review of this work. Peer reviewer reports are available.

Reprints and permission information is available at http://www.nature.com/reprints

Publisher's note Springer Nature remains neutral with regard to jurisdictional claims in published maps and institutional affiliations. (c) (i) Open Access This article is licensed under a Creative Commons Attribution 4.0 International License, which permits use, sharing, adaptation, distribution and reproduction in any medium or format, as long as you give appropriate credit to the original author(s) and the source, provide a link to the Creative Commons license, and indicate if changes were made. The images or other third party material in this article are included in the article's Creative Commons license, unless indicated otherwise in a credit line to the material. If material is not included in the article's Creative Commons license and your intended use is not permitted by statutory regulation or exceeds the permitted use, you will need to obtain permission directly from the copyright holder. To view a copy of this license, visit http://creativecommons.org/ licenses/by/4.0/.

(C) The Author(s) 2020 